\title{
New Eoblattida (Insecta) from the Permian of Russia
}

\author{
Новые Eoblattida (Insecta) из перми России
}

\author{
Alexandr P. Rasnitsyn ${ }^{1,2} \&$ Danil S. Aristov ${ }^{3}$ \\ А.П. Расниџын, А.С. Аристов
}

\begin{abstract}
${ }^{1}$ Paleontological Institute, Russian Academy of Sciences, Profsoyuznaya, 123, 117997 Moscow, Russia. E-mail: rasna36@yahoo.com.
${ }^{2}$ Natural History Museum, London, SW7 5BD, England.

${ }^{3}$ Paleontological Institute, Russian Academy of Sciences, Profsoyuznaya, 123, 117997 Moscow, Russia. E-mail: danil_aristov@mail.ru. Палеонтологический институт РАН, Профсоюзная ул. 123, 117997 Москва, Россия.
\end{abstract}

KEY WORDS: Fossil insects, Eoblattida, Permian.

КЛЮЧЕВЫЕ СЛОВА: Ископаемые насекомые, Eoblattida, пермь.

ABSTRACT. Described are Kungurembia biarmica Rasnitsyn et Aristov, sp. n. (Eoblattida: Tillyardembiidae) from the Middle Permian (Lower Kazanian) of Soyana and Permeoblatta borealis Rasnitsyn et Aristov, gen. et sp.n. (Eoblattida incertae familiae) from the Late Permian (Severodvinian) of Isady, both in the northern European Russia. P. borealis is the latest representative of the order known mainly from the Carboniferous of the North and South America and Eurasia. Structure of the order is Eoblattida discussed.

РЕЗЮМЕ. Описаны новые пермские Eoblattida (Insecta) Kungurembia biarmica Rasnitsyn et Aristov, sp. n. (семейство Tillyardembiidae) из нижнеказанского местонахождения Сояна в Архангельской обл. и Permeoblatta borealis Rasnitsyn et Aristov, gen. et sp.n. (Eoblattida incertae familiae) из северодвинских Исад в Вологодской обл. P. borealis является наиболее молодым представителем отряда, известного преимущественно из карбона Северной и Южной Америки и Евразии. Обсуждается структура отряда Eoblattida.

\section{Introduction}

Until recently, the extinct order Eoblattida has been considered as strictly Carboniferous in the time range [e.g., Rasnitsyn \& Quicke, 2002]. It has been extended into the late Early Permian when the family Tillyardembiidae has been found rooted within Eoblattida rather than within Grylloblattida. This family consists of four species Tillyardembia antenaeplana G. Zalessky, 1937, T. ravisedorum Vilesov et Novokshonov, 1993, Kungurembia brevicervix Aristov, 2004 and K. pallida Aristov, 2004, all known from the Kungurian (latest Early Permian) of the Perm Region at Urals Mts. [Aristov \& Rasnitsyn, 2010].

One of the fossils described herein, Kungurembia biarmica sp.n. (Figs 25-27) from the fossil site Soyana
(Early Kazanian of Arkhangelsk Reg.) belongs to Tillyardembiidae and so needs little general discussion beyond the statement that the family has survived in the Middle Permian and extended its geographic range to what is now the northern European Russia.

The other fossil at hand, Permeoblatta borealis gen. et sp.n. (Figs 28-30) from the Late Permian locality Isady (Severodvinian stage of Vologda Reg., northern European Russia) is much more unusual, firstly because it extends the time range of the order well into the Late Permian. Secondly, whilst Tillyardembiidae is a taxon distinctly apomorphic in respect to the main Carboniferous body of the order, the fossil in question looks alike these ancient forms thus making its so late record as completely unexpected. As a result, this find needs more diversified comparison to be properly described. This is not an easy task, particularly because the structure and limits of the order Eoblattida are far from being well understood [Rasnitsyn \& Quicke, 2002; Aristov \& Rasnitsyn, 2009].

Following the refined traditional approach to taxonomy [called phyletics: Rasnitsyn, 2006], we start our attempt to define structure of the order with identification of its core components. The type genus Eoblatta Handlirsch, 1906 (Fig. 1) is the unquestionable centre surrounded with the similar and putatively closely related taxa including Stenoneura Brongniart, 1893, Anegertus Handlirsch, 1911, Lobeatta Béthoux, 2005, Nectoptilus Béthoux, 2005, Ctenoptilus Lameere, 1917, Ischnoptilus Brongniart, 1893, Paranarkemina Pinto et Pinto de Ornellas, 1980, Cacurgulopsis Pinto et Adami-Rodrigues, 1995 (Figs 2-8), and others. All of them share the fore wing of large size and with more or less wide costal space, with SC meeting R, with RS started early and running close to R (less so in Lobeatta, Paranarkemina and Cacurgulopsis), with $\mathrm{CuA}$ abundantly branched and forming backward comb often intergrading into a more or less irregular fan or bunch, and with the anal region of the characteristic cockroach-like form, even though sometimes of somewhat diminished size. 
Approaching to this core assemblage are several groups which are equally cannot be attested as clear cut. One of these embraces taxa with $\mathrm{CuA}$ arranged into two

facing combs jointly forming a wide fan (a supposed apomorphy) (Figs 9-16). Most of them have RS starting late and running distant of $\mathrm{R}$ (a putative plesiomorphy).
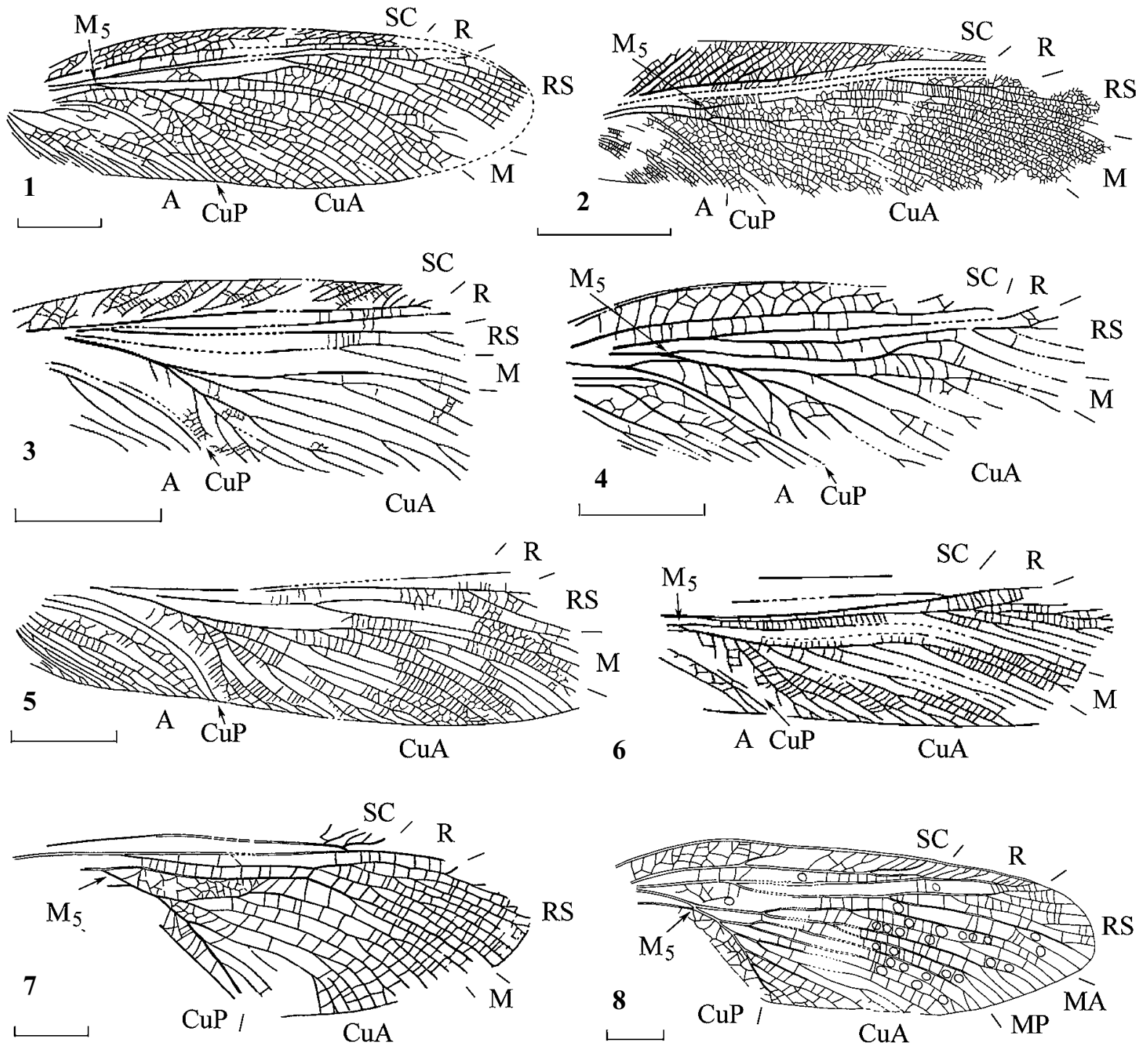

Figs 1-8. The core group of the order Eoblattida: 1 - Eoblatta robusta (Brongniart, 1893) [Commentry, Allier, France; Gzhelian or Kasimovian Stage of Upper Carboniferous; after Béthoux \& Nel, 2005]; 2 - Stenoneura fayoli Brongniart, 1893 [Commentry, Allier, France; Gzhelian or Kasimovian Stage of Upper Carboniferous; modified after Béthoux \& Nel, 2005: R and RS added in dashed lines based on personal observation of the holotype]; 3 - Anegertus cubitalis Handlirsch, 1911 [Mazon Creek, Illinois, USA; Moscovian Stage of Middle Carboniferous; after Béthoux, 2005]; 4 - Lobeatta schneideri Béthoux, 2005 [Mazon Creek, Illinois, USA; Moscovian Stage of Middle Carboniferous; after Béthoux, 2005]; 5 - Nectoptilus mazonus Béthoux, 2005 [Mazon Creek, Illinois, USA; Moscovian Stage of Middle Carboniferous; after Béthoux, 2005]; 6 - Ctenoptilus elongatus (Brongniart, 1893) [Commentry, Allier, France; Gzhelian or Kasimovian Stage of Upper Carboniferous; after Béthoux \& Nel, 2005]; 7 — Paranarkemina kurtzi Pinto et Ornellas, 1980 [Bajo de Veliz, Provincia de San Luis, Argentina; Gzhelian or Kasimovian Stage of Upper Carboniferous; after Pinto \& Ornellas, 1980], 8 - Cacurgulopsis sanguinettiae Pinto et Adami-Rodrigues, 1995 [Boituva, San Paolo State, Brasil;Upper Carboniferous; after Pinto \& Adami-Rodrigues, 1995]. Scale bar in Figs 1, 19, 29-30-5 mm; in Figs 2-18, 20-24-10 mm; in Fig. $27-2 \mathrm{~mm}$. Venational symbols in all figures are customary.

Рис. 1-8. Центральная группа родов отряда Eoblattida: 1 - Eoblatta robusta (Brongniart, 1893) [Комментри, Алье, Франция; гжельский или касимовский ярус верхнего карбона; по Béthoux \& Nel, 2005]; 2 - Stenoneura fayoli Brongniart, 1893 [Комментри, Алье, Франция; гжельский или касимовский ярус верхнего карбона; по Béthoux \& Nel, 2005, с изменениями: добавлены пунктиром жилки R и RS; голотип, собственные данные]; 3 - Anegertus cubitalis Handlirsch, 1911 [Мэзон Крик, Иллинойс, США; московский ярус среднего карбона; по Béthoux, 2005]; 4 - Lobeatta schneideri Béthoux, 2005 [Мэзон Крик, Иллинойс, США; московский ярус среднего карбона; по Béthoux, 2005]; 5 - Nectoptilus mazonus Béthoux, 2005 [Мэзон Крик, Иллинойс, США; московский ярус среднего карбона; по Béthoux, 2005]; 6 - Ctenoptilus elongatus (Brongniart, 1893) [Комментри, Алье, Франция; гжельский или касимовский ярус верхнего карбона; по Béthoux \& Nel, 2005]; 7 - Paranarkemina kurtzi Pinto et Ornellas, 1980 [Байо де Велиз, пров. Сан-Луис, Аргентина; гжельский или касимовский ярус верхнего карбона; по Pinto \& Ornellas, 1980], 8 - Cacurgulopsis sanguinettiae Pinto et AdamiRodrigues, 1995 [Бойтуве, штат Сан-Пауло, Бразилия; верхний карбон; по Pinto \& Adami-Rodrigues, 1995]. Длина масштабной линейки на Рис. 1, 19, 29-30 - 5 мм; на Рис. 2-18, 20-24-10 мм; на Рис. $27-2$ мм. Обозначения жилок на всех рисунках стандартные. 
Majority of them additionally have $\mathrm{M}$ branches anastomosed with RS and CuA (Aetophlebia Scudder, 1885, Bouleites Lameere, 1917, Narkemina Martynov, 1930,
Narkeminopsis Walley, 1979; this character state is apparently apomorphic as well). Approaching this group are taxa with subbasal, posterior $\mathrm{M}$ branch short and
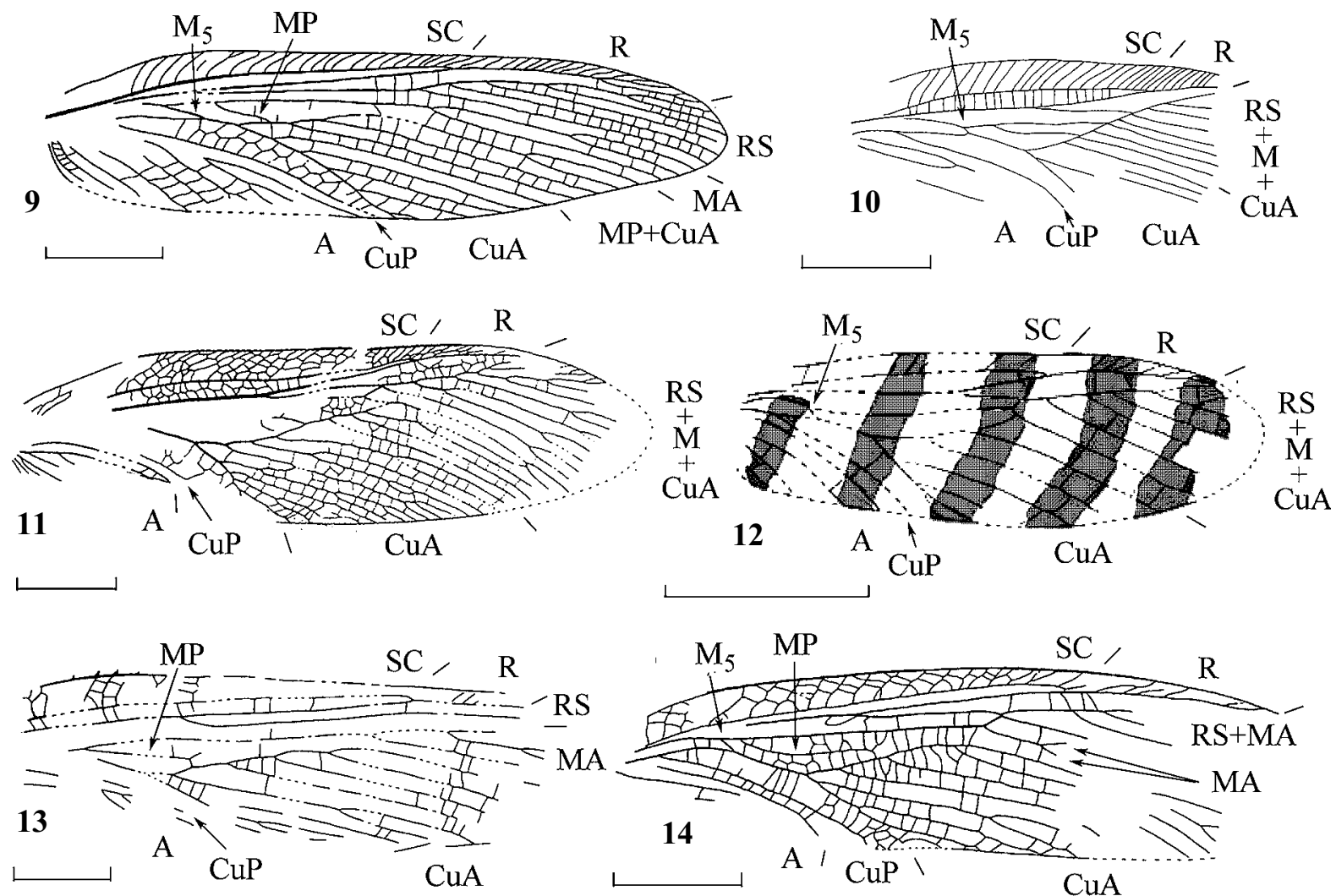

M5 MP

$\mathrm{SC}$,
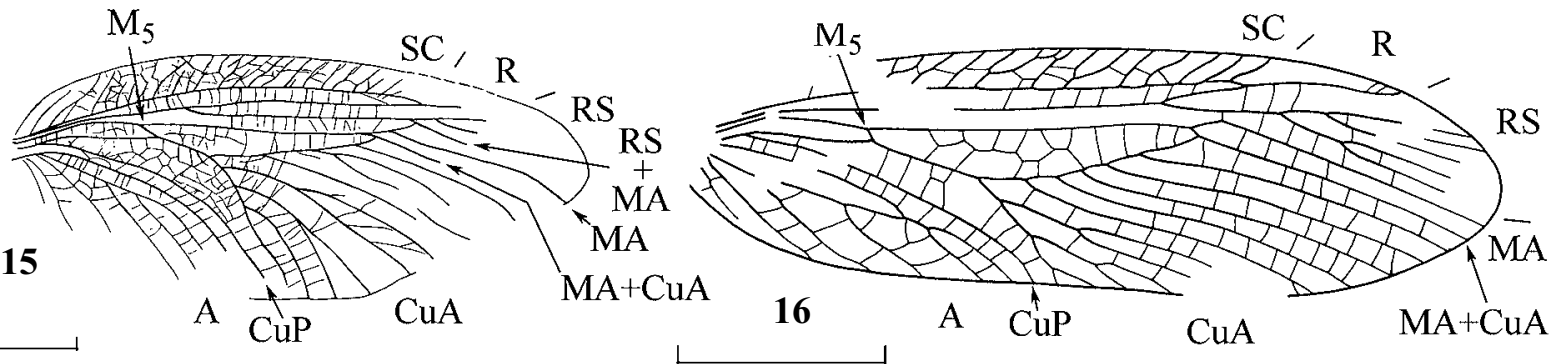

Figs 9-16. "Narkemina" genus group: 9 - Ischnoneura oustaleti (Brongniart, 1885) [Commentry, Allier, France; Gzhelian or Kasimovian Stage of Upper Carboniferous; after Béthoux \& Nel, 2005]; 10 - Aetophlebia singularis Scudder, 1885 (Mazon Creek, Illinois, USA; Moscovian Stage of Middle Carboniferous; orig.); 11 - Bouleites latipennis Lameere 1917 [Commentry, Allier, France; Gzhelian or Kasimovian Stage of Upper Carboniferous; after Béthoux \& Nel, 2005]; 12 - Narkeminopsis eddyi Walley, 1979 [Radstock, Avon, England; Moscovian Stage of Middle Carboniferous; after Béthoux \& Nel, 2005]; 13 - Cnemidolestes (Brongniart, 1893) [Commentry, Allier, France; Gzhelian or Kasimovian Stage of Upper Carboniferous; after Béthoux \& Nel, 2005]; 14 — Protodiamphipnoa gaudryi (Brongniart 1885) [Commentry, Allier, France; Gzhelian or Kasimovian Stage of Upper Carboniferous; after Béthoux \& Nel, 2005]; 15 - Paranarkemina amosi Pinto, 1992 [Bajo de Veliz, Provincia de San Luis, Argentina; Gzhelian or Kasimovian Stage of Upper Carboniferous; after Pinto, 1992]; 16 - Narkemina cf. angustata Martynov, 1931 (Chunia, Krasnoyarsk Territory, Russia; Middle or Upper Carboniferous; orig.).

Рис. 9-16. Группа родов "Narkemina": 9 - Ischnoneura oustaleti (Brongniart, 1885) [Комментри, Алье, Франция; гжельский или касимовский ярус верхнего карбона; по Béthoux \& Nel, 2005]; 10 - Aetophlebia singularis Scudder, 1885 (Мэзон Крик, Иллинойс, США; московский ярус среднего карбона; ориг.); 11 - Bouleites latipennis Lameere 1917 [Комментри, Алье, Франция; гжельский или касимовский ярус верхнего карбона; по Béthoux \& Nel, 2005]; 12 - Narkeminopsis eddyi Walley, 1979 [Рэдсток, Авон, Англия; московский ярус среднего карбона; верхний карбон; по Béthoux \& Nel, 2005]; 13 - Cnemidolestes (Brongniart, 1893) [Комментри, Алье, Франция; гжельский или касимовский ярус верхнего карбона; по Béthoux \& Nel, 2005]; 14 — Protodiamphipnoa gaudryi (Brongniart 1885) (Комментри, Алье, Франция; гжельский или касимовский ярус верхнего карбона; по Béthoux \& Nel, 2005]; 15 - Paranarkemina amosi Pinto, 1992 [Байо де Велиз, пров. Сан-Луис, Аргентина; гжельский или касимовский ярус верхнего карбона; по Pinto, 1992]; 16 — Narkemina cf. angustata Martynov, 1931 (Чуня, Красноярский край, Россия; средний или верхний карбон; ориг.). 

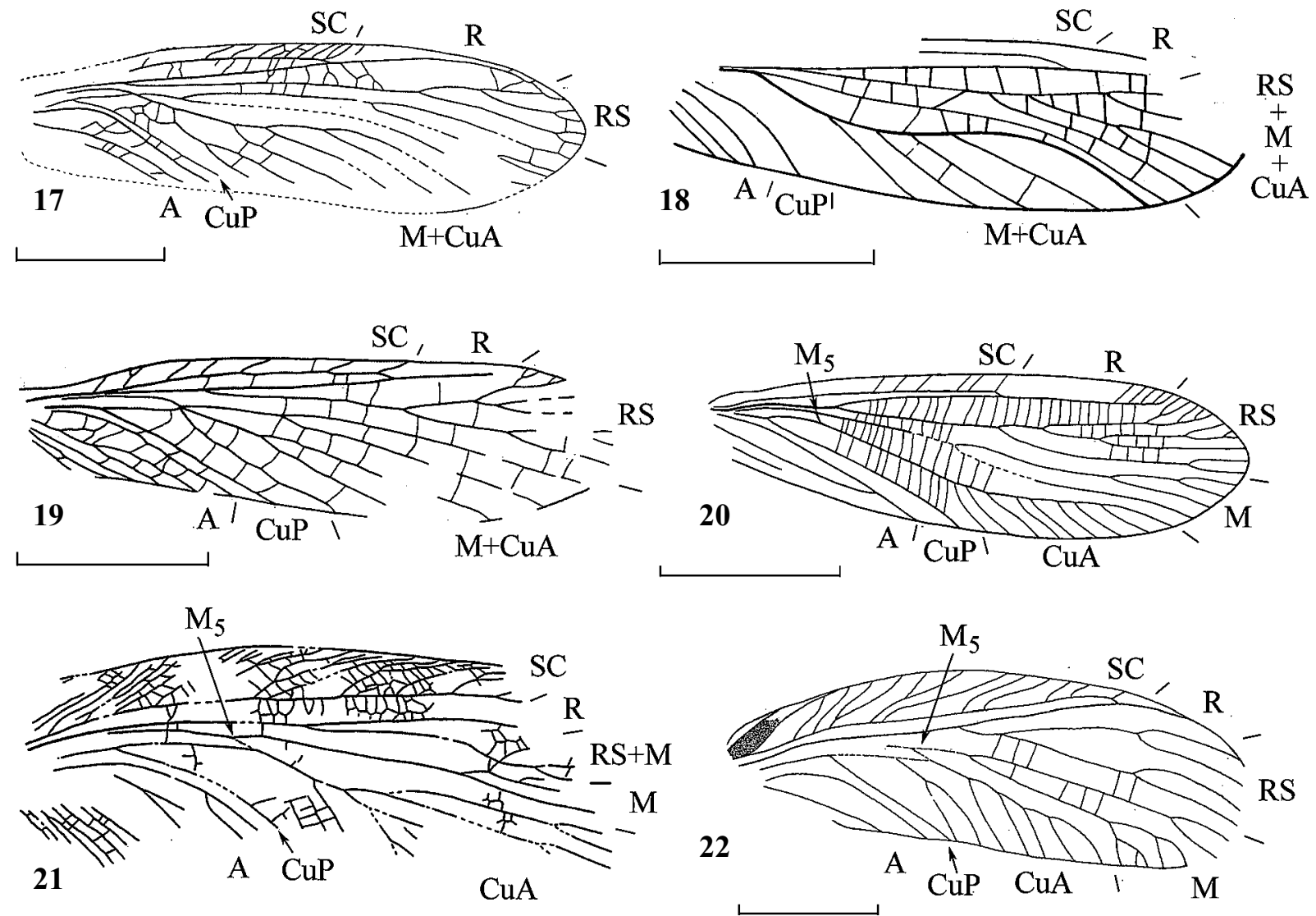

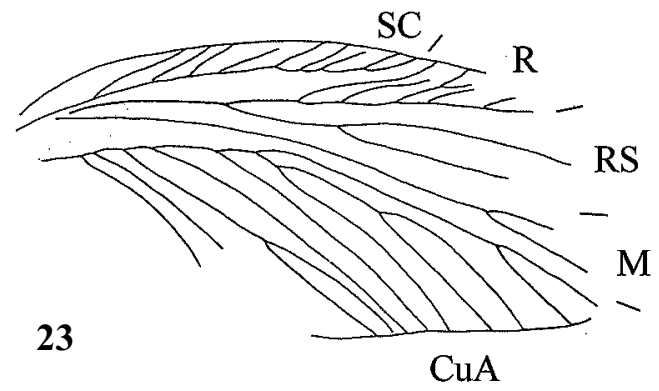

$\mathrm{CuA}$

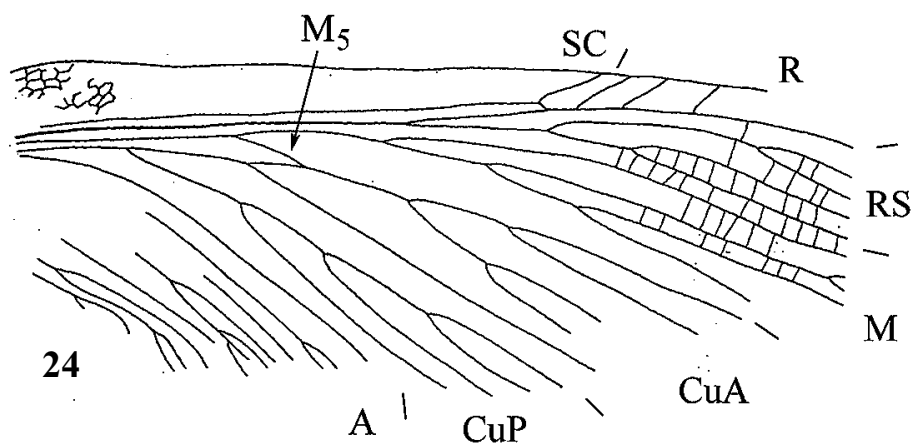

Figs 17-24. Spanioderidae (17-19), Tillyardembiidae (20), and various genera: 17 - Miamia bronsoni Dana, 1864 [Mazon Creek, Illinois, USA; Moscovian Stage of Middle Carboniferous; after Béthoux, 2008]; 18 - Dieconeura arquata Scudder 1885 [Mazon Creek, Illinois, USA; Moscovian Stage of Middle Carboniferous; after Aristov \& Rasnitsyn, 2009]; 19 - Anthraconeura silvatica Laurentiaux et Laurentiaux-Vieira, 1980 [Pas-de-Calais, France; Moscovian Stage of Middle Carboniferous; after Béthoux, 2008]; 22 — Tillyardembia antennaeplana G. Zalessky, 1937 [Chekarda, Perm Territory, Russia; Kungurian Stage of Lower Permian; after Aristov \& Rasnitsyn, 2009]; 21 - Protophasma dumasi Brongniart, 1879 [Commentry, Allier, France; Gzhelian or Kasimovian Stage of Upper Carboniferous; after Béthoux, 2003]; 22 - Cheliphlebia carbonaria Scudder, 1885 (Mazon Creek, Illinois, USA; Moscovian Stage of Middle Carboniferous; orig.); 23 - Gerapompus extensus Scudder, 1885 (Mazon Creek, Illinois, USA; Moscovian Stage of Middle Carboniferous; orig.); 24 Polyernus complanatus Scudder, 1885 (Mazon Creek, Illinois, USA; Moscovian Stage of Middle Carboniferous; orig.).

Рис. 17-24. Spanioderidae (17-19), Tillyardembiidae (20), и другие роды Eoblattida: 17 - Miamia bronsoni Dana, 1864 [Мэзон Крик, Иллинойс, США; московский ярус среднего карбона; по Béthoux, 2008]; 18 - Dieconeura arquata Scudder 1885 [Мэзон Крик, Иллинойс, США; московский ярус среднего карбона; по Aristov \& Rasnitsyn, 2009]; 19 - Anthraconeura silvatica Laurentiaux et Laurentiaux-Vieira 1980 [Па-де-Кале, Франция; московский ярус среднего карбона; по Béthoux, 2008]; 20 - Tillyardembia antennaeplana G. Zalessky, 1937 [Чекарда, Пермский край, Россия; кунгурский ярус нижней перми; по Aristov \& Rasnitsyn, 2009]; 21 - Protophasma dumasi Brongniart, 1879 [Комментри, Алье, Франция; гжельский или касимовский ярус верхнего карбона; по Béthoux, 2003]; 22 - Cheliphlebia carbonaria Scudder, 1885 (Мэзон Крик, Иллинойс, США; московский ярус среднего карбона; ориг.); 23 - Gerapompus extensus Scudder, 1885 (Мэзон Крик, Иллинойс, США; московский ярус среднего карбона; ориг.); 24 Polyernus complanatus Scudder, 1885 (Мэзон Крик, Иллинойс, США; московский ярус среднего карбона; ориг.). 
often blind, viz., Cnemidolestes Handlirsch, 1906, Protodiamphipnoa Brongniart, 1893, Ischnoneura Brongniart, 1893. This basal branch is apparently MP which is probably lost in Aetophlebia, Bouleites, Narkemina, and Narkeminopsis, judging from far distal branching of their supposed MA. Cnemidolestes and Ischnoneura additionally have RS starting basal and running parallel to $\mathrm{R}$, although not so far basal and not as tight to $\mathrm{R}$ as in Eoblatta and majority of its allies. However, species of Paranarkemina (Figs 5-8, 15) make the demarcation of "Eoblatta group" and "Narkemina group" hardly possible. They display basal RS origin like in the former group, combined in case of $P$. amosi Pinto, 1992 with MA anastomosing with RS and $\mathrm{CuA}$ precisely like in the latter. This makes phylogenetic interpretation of the far basal vs. distal position of the RS base as obscure in this particular case.

One more allied assemblage is formed with the genera Miamia Dana, 1864 (known also as Spaniodera Handlirsch, 1906, Propteticus Scudder, 1885, etc.) and Dieconeura Scudder, 1885, along with their probable relative Anthraconeura Laurentiaux \& Laurentiaux-Vieira, 1980 [cf. Béthoux, 2008] which differs from the core one in three main points (Figs 17-19). They have the costal space narrow and $\mathrm{M}_{5}$ lost due to $\mathrm{M}$ and $\mathrm{CuA}$ coalescent either in one point (Anthraconeura) or for a distance (Miamia, Dieconeura); both character states being probably apomorphic. Additionally, their RS starts less early and running less close to RS than in the Eoblatta etc. (plesiomorphy). Tillyardembiidae (Fig. 20 ) is hypothesised to be a dwarf offshoot of that line, a Permian relict deviated from the common ancestor before it had free $M_{5}$ lost [Aristov \& Rasnitsyn, 2009].

There are several more taxa approaching the core assemblage individually and forming no distinct groups (Figs 21-24). They differ from the above groups and are apparently plesiomorphic in their respect in displaying comparatively late origin of RS combined with the wide costal space and rich $\mathrm{CuA}$ not forming a pair of facing combs. These are, e.g., Protophasma Brongniart, 1879, Cheliphlebia Scudder, 1885, Gerapompus Scudder, 1885, Polyernus Scudder, 1885, etc. Permeoblatta (Figs 28-30) falls here as well. The group is loose having little or no more characters in common. Indeed, Cheliphlebia has SC entering R [like in all above assemblages, a plesiomorphy after Aristov \& Rasnitsyn, 2010]. However, it has $\mathrm{CuA}$ comparatively poor in branching (apomorphy). Gerapompus (based on the studied holotype of $G$. extensus Scudder, 1885) has SC meeting $\mathrm{C}$ and not $\mathrm{R}$ (apomorphy), while the other genera in the present assemblage have SC incomplete distally. Polyernus is unique in having $\mathrm{CuP}$ branching (plesiomorphy unless reversal). Permeoblatta gen.n. differs from apparently all Eoblattida in having a very dense archedictyon. Judging from Paoliida, the most basal taxon of the winged insects [Rasnitsyn \& Quicke, 2002], such a dense archedictyon is not the ground plan character of Pterygota. Rather, it has been gained by the new genus in homoplasy with cockroaches, palaeodictyopterons and dragonflies. In general, we have to consider Permeoblatta gen. nov. as a Carboniferous relict in the Late Permian.

In the present analysis, we set aside Geraridae and their relatives, because their monophyly with the Orthopteroid orders can be taken as sufficiently grounded [Sharov, 1968; Gorokhov, 2001, 2004]. Nor we consider the Carboniferous fossils often referred to as Cacurgus group, Omalia group, Heterologus group, etc. [cf. Brauckmann, 1991], because they differ still more from the core Eoblattida in lacking the cockroach-like clavus. They can be easily found representing archaic Cimiciformes rather than Eoblattida, as the case of Heterologopsis Brauckmann et Koch, 1982 suggests [see Rasnitsyn \& Quicke, 2002, for details].

There are other taxa beyond those mentioned above which may belong to Eoblattida. Nevertheless, we stop discussing the problem in more detail here because further advance needs re-study of types of the respective taxa, a task lying beyond the framework of the present publication. Nor we will set the family level taxonomy in the assemblages outlined above, because they are not clear cut enough to draw convincing borderlines inbetween, and again in appreciation of necessity of the extensive type revision. Our immediate goal was to seek for potential kin of Permeoblatta gen. nov., and we apparently approach it. Even though we are not able to indicate a particular family yet to subordinate it, it is possible to conclude now that the new genus is most probably belongs to the order Eoblattida and is somehow related to Protophasma.

Both fossils described herein as new are unique and most probably represent rare taxa. The sole specimen of $K$. biarmica sp.n. is found among 5000 insect fossils collected in Soyana, and the unique holotype of $P$. borealis is one of a thousand fossils collected in Isady.

\section{Order Eoblattida Handlirsch, 1906}

Family Tillyardembiidae G. Zalessky, 1938

\section{Kungurembia biarmica Rasnitsyn et Aristov, sp.n. Figs 25-27}

MATERIAL. Holotype PIN no. 3353/144; part and counterpart imprint of entire insect with wings ill-preserved; Soyana locality, right bank of Soyana River $56-60 \mathrm{~km}$ from mouth, Mezen' District, Arkhangel'sk Region, Russia; Iva-Gora Beds, Lower Kazanian Substage, Middle Permian. Paratype PIN, 3353/ 176; part and counterpart imprint of entire insects with wings illpreserved; same locality; A.G. Sharov leg. 1972; kept in Paleontological Institute, Russian Academy of Science, Moscow.

DESCRIPTION. Length of body $13 \mathrm{~mm}$, forewing 11-12 $\mathrm{mm}$, hindwing 9.5-10.5 $\mathrm{mm}$. Head prognathous, tapering forward, slightly longer than wide. Eyes large, antennae probably short, with flagellomeres elongate, widened apically. Pronotum smaller than head, trapezoid, slightly narrowing forward, width 1.3 times length. Mesonotum as long as wide, scutum rounded triangular, elongate, with prescutum weakly convex, not large, lateral lobes large, separated. Metanotum as long as wide, with scutum wider than mesoscutum, rounded triangular, as long as wide, with prescutum weakly convex, not large. Legs short, fore and mid ones of similar size, hind pair larger, tibiae half as wide as femora. Forewing with 

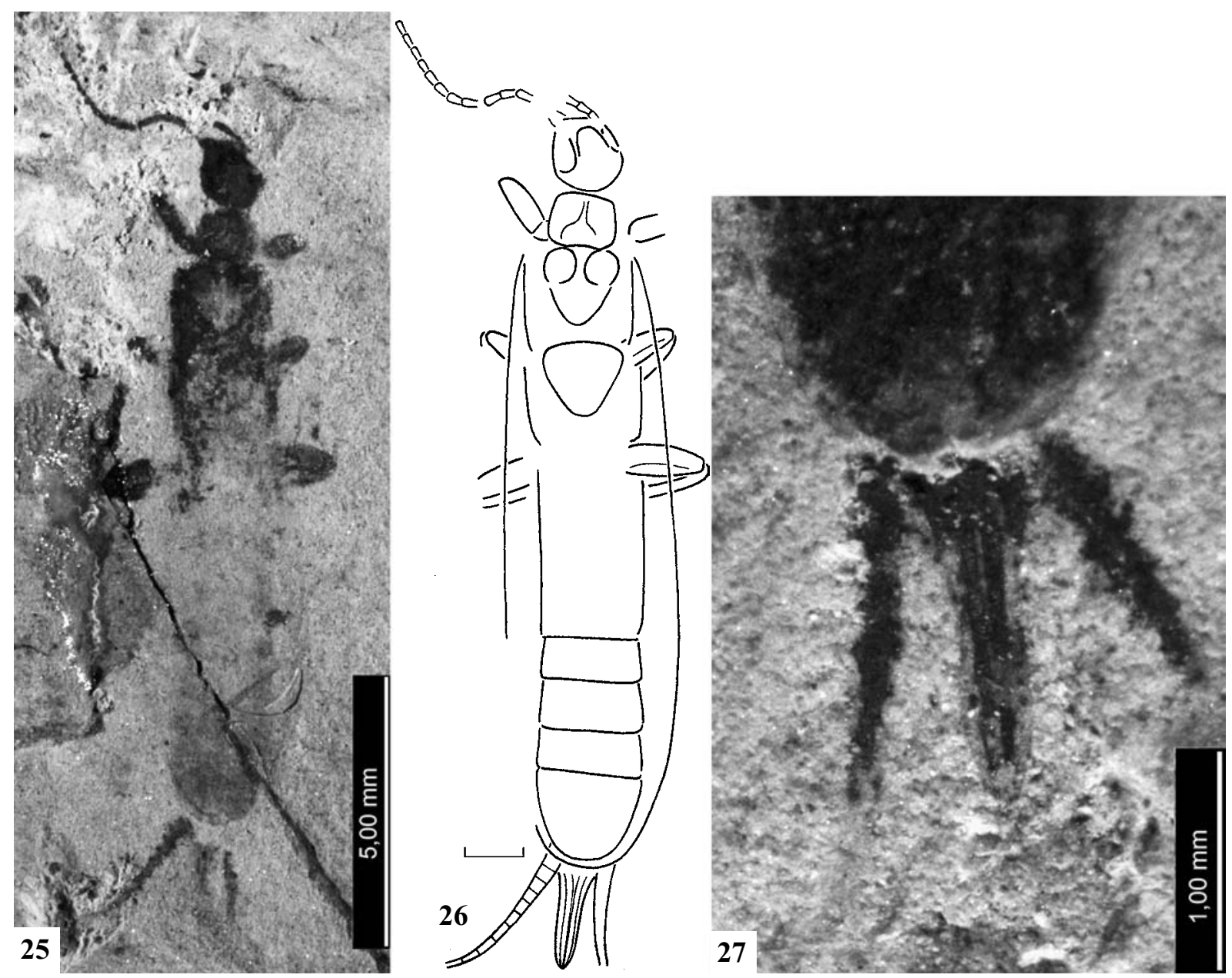

Figs 25-27. Kungurembia biarmica Rasnitsyn et Aristov, sp. n., holotype PIN, no. 3353/144: 25 - female body from above; 26 ovipositor; 27 - female body from above, interpretation (Soyana, Russia, Middle Permian).

Рис. 25-27. Kungurembia biarmica Rasnitsyn et Aristov, sp. n., голотип ПИН, № 3353/144: 25 — тело самки сверху; 26 — яйцеклад; 27 - тело самки сверху (Сояна, Россия, средняя пермь).

fore margin weakly convex, venation not preserved. Abdomen reaching apices of closed wings. Cerci short, wide basally, sharply narrowed toward apex, with basal segments short, growing longer apically. Ovipositor strong, comparatively short, not much tapering.

COMPARISON. New species is attributed to the genus Kungurembia based on similar form of the pronotum. It is very similar to $K$. brevicervix Aristov, 2004 from the Kungurian locality Tshekarda in the Perm Territory [Aristov, 2004] but differs in having metanotum larger, ovipositor shorter and wider in distal half, and basal cercomeres shorter. Unfortunately wing venation is unknown in the new species, because all Tillyardembiidae have weak veins which preserve only in exceptional fossils.

ETYMOLOGY. Species name is after the Biarmian Epoch of the Permian Period.

\section{Eoblattida incertae familiae}

Permeoblatta Rasnitsyn et Aristov, gen. n.

TYPE SPECIES. P. borealis sp.n.

DIAGNOSIS. Forewing large, some 3 times as long as wide, with dense archedictyon (particularly so in anteroba- sal wing portion), with fore margin moderately convex. Costal space more than three times as wide as subcostal at level of clavus apex. SC with fore branches moderately long, oblique, and simple (only with small apical branchlets), less commonly branching, apex not preserved. RS starts at or slightly beyond wing midlength, distant from R, not preserved shortly after RS base. M simple at least till somewhat beyond wing midlength. $\mathrm{M}_{5}$ moderately short, slightly S-like bent, placed near wing base. $\mathrm{CuA}$ taking more than half wing width, reaching near wing apex, branching abundantly and irregularly. CuP strongly arching basally, straight since about level of $\mathrm{M}_{5}$, simple. Clavus lanceolate, near symmetrical, 3 anal veins almost straight, simple (unless the last two both represent early forking 2A) except for short apical branchlets, each meeting hind margin at a distance.

COMPOSITION. Type species only.

COMPARISON. Wide costal space combined with far distal origin of RS, abundant irregular branching of $\mathrm{CuA}$, and simple CuP differ the new genus from all better known Eoblattida but Protophasma (see Introduction for more thorough comparison). Dense archediction is unique within Eoblattida. 


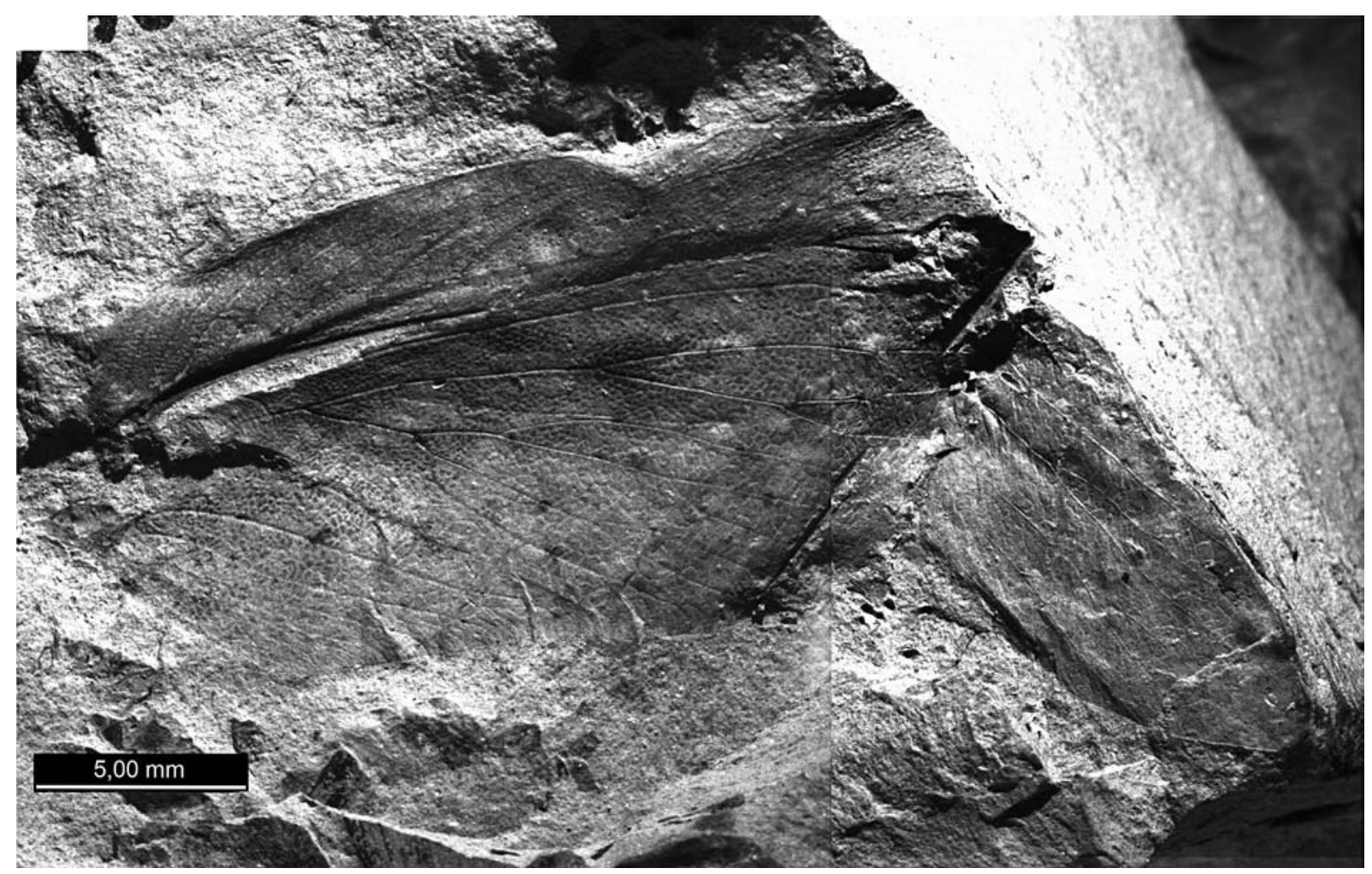

Fig. 28. Permeoblatta borealis Rasnitsyn et Aristov, gen. et sp. n., holotype PIN, no. 3840/845, forewing, the fossil (Isady, Russia, Upper Permian).

Рис. 28. Permeoblatta borealis Rasnitsyn et Aristov, gen. et sp. n., голотип ПИН, № 3840/845, переднее крыло, фото отпечатка (Исады, Россия, Верхняя Пермь).

REMARKS. Attribution of the new genus to Eoblattida and not to any of orders better expectable to occur in the Permian based on the following combinations of characters. It differs from cockroaches (order Blattida) in having SC long and well individualised, RS individualised and R not abundantly branching basal of RS base, and clavus rather small. It differs from the order Grylloblattida in having M simple for the most of its length, and more abundant branching of $\mathrm{CuA}$. It differs from the order Hypoperlida (which sometimes has a kind of archedictyon and distinct even though rather small clavus) in its structure of SC: when (rarely) the costal space is comparably wide in that order, then SC shows long and characteristically slanting fore branches (like in Strephocladus Scudder, 1884, Strephoneura Martynov, 1940, Homocladus Carpenter, 1966, Adiphlebia Scudder, 1885, Mesoptilus Lameere, 1917, etc.). Other insect orders are still more different from Permeoblatta.

The reason why the new genus is described as incertae familiae is the present poor state of the family level taxonomy of the order Eoblattida (see Introduction for detail).

ETYMOLOGY. The genus name is after the Permian Period and genus Eoblatta. Gender feminine.

Permeoblatta borealis Rasnitsyn et Aristov, sp.n. Figs 28-30

MATERIAL. Holotype PIN no. 3840/845; part and counterpart of damaged forewing with apical part missed anteriorly and bent rearward posteriorly; fossil site Isady (= Mutovino), left bank of the Sukhona River, $1.8 \mathrm{~km}$ downstream of the Mutovino place opposite the village of Isady, Velikoustyugskii District, Vologda Region, Russia; Kichug Member of the Poldarsa Formation, Severodvin- ian Stage, Upper Permian; collected by the PIN Team 2009; kept in Paleontological Institute, Russian Academy of Science, Moscow.

DESCRIPTION. Forewing $32 \mathrm{~mm}$ long as preserved, somewhat darkened basally and in fore half, with short dark marks scattered along veins and particularly in forks. SC with 11 preserved branches, simple or, two penultimate ones, apically forked. RS base at level between $10^{\text {th }}$ and $11^{\text {th }} \mathrm{SC}$ branches. $\mathrm{M}_{5}$ meeting $\mathrm{CuA}$ shortly before first $\mathrm{CuA}$ fork. $\mathrm{CuA}$ with 13 branches, branching rather evenly through its length, one of inner second order branches lost blind in archediction. Three anal veins very slightly S-like bent, ending in a bunch of small branchlets. Hind part of wing with archedictyon transformed into larger cells in 2-4 irregular rows between longitudinal veins (no real crossvein present).

ETYMOLOGY. The species name borealis is the Latin for northern.

ACKNOWLEDGEMENTS. The present study is supported in part by the Presidium RAS Program "Origin and evolution of Biosphere" and the Russian Foundation for Basic Research Grant \# 09-04-01241.

\section{References}

Aristov D.S. 2004. The Fauna of Grylloblattid Insects (Grylloblattida) of the Lower Permian Locality of Tshekarda // Paleontol. J. Vol.38. suppl.2. P.80-145.

Aristov D. S. \& Rasnitsyn A.P. 2010. The family Tillyardembiidae Zalessky, 1938 and the system of the plecopteroid insects) // Russian Entomol. J. Vol.18 (for 2009). No.3. P.257-264. 


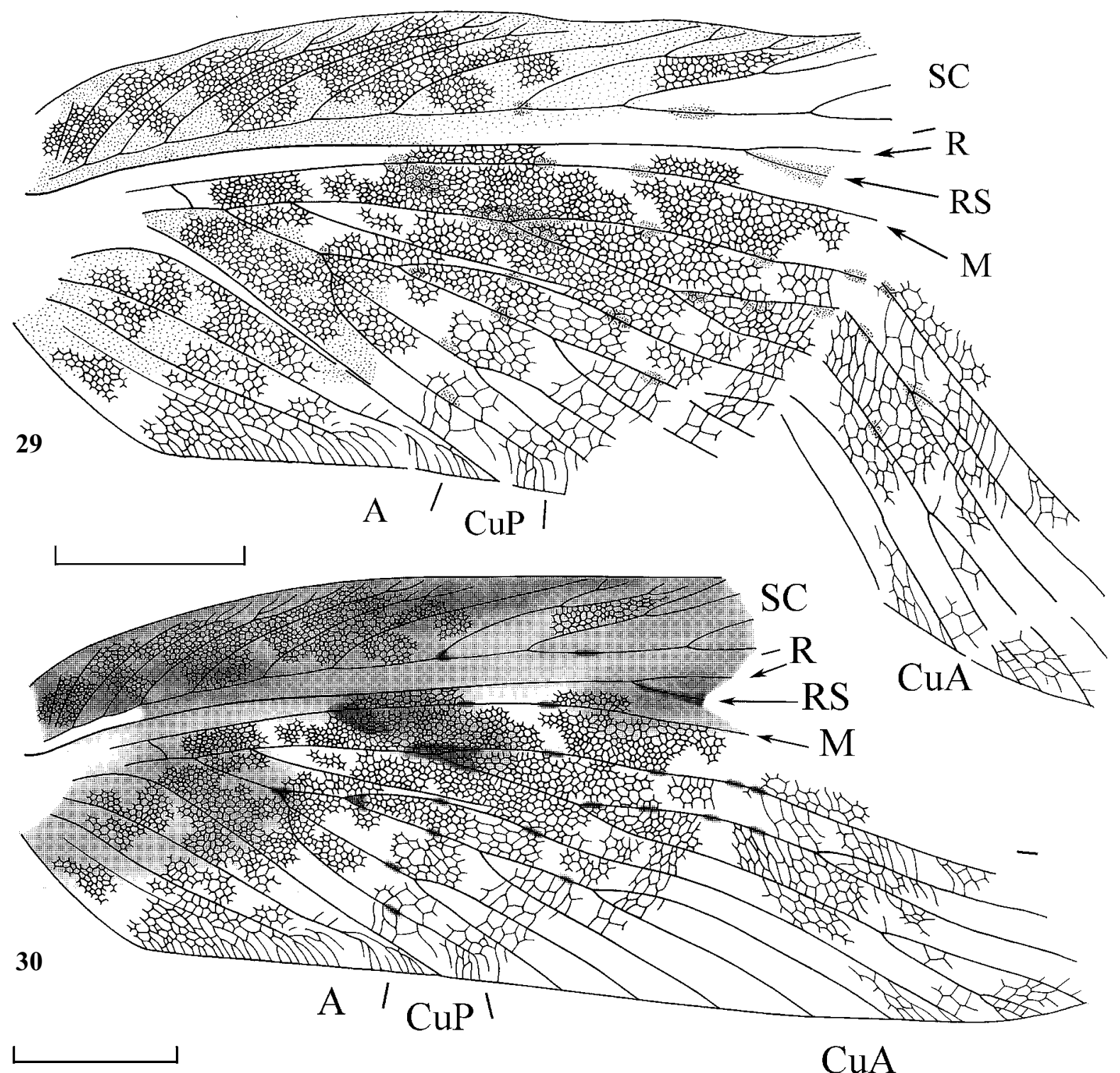

Figs 29-30. Permeoblatta borealis Rasnitsyn et Aristov, gen. et sp. n., holotype PIN, no. 3840/845, forewing: 29 — its interpretation; 30 - restored (Isady, Russia, Upper Permian).

Рис. 29-30. Permeoblatta borealis Rasnitsyn et Aristov, gen. et sp. n., голотип ПИН, № 3840/845, переднее крыло: $29-$ его интерпретация в исходном состоянии; 30 - реконструкция (Исады, Россия, верхняя пермь).

Béthoux O. 2003. Protophasma dumasii Brongniart, 1879, a link between Orthoptera and the 'dictyopterid' orders // Journal of Orthoptera Research. Vol.12. P.57-62.

Béthoux O. 2005. Reassigned and new basal Archaeorthoptera from the Upper Carboniferous of Mazon Creek (IL, USA) // Journal of Orthoptera Research. Vol.14. P.121-126.

Béthoux O. 2008. Revision and Philogenetic Affinities of the Lobeattid Species bronsoni Dana, 1864 and sylvatica Laurentiaux et Laurentiaux-Vieira, 1980 (Pensilvanian; Archeorthoptera) // Artropod Systematics \& Phylogeny. Vol.66. No.2. P.145-163.

Béthoux O. \& Nel A. 2005. Some Palaeozoic 'Protorthoptera' are 'ancestral' orthopteroids: major wing braces as clues to a new split among the 'Protorthoptera' // Journal of Systematic Palaeontology. Vol.2. P.284-309.

Brauckmann C. 1991. Arachniden und Insekten aus dem Namurium von Vorhalle-Schichten (Ober-Karbon, West-Deutschland) // Veröff.Fuhlrott-Mus. Bd.1. S.1-275.

Gorochov A.V. 2001. On the higher classification of the Polyneoptera (short course) // Acta geol. leopold. Vol.24. Nos.52/
53. P.11-56.

Gorochov A.V. 2004. [Primitive Titanoptera and the Early Evolution of the Polyneoptera] // Lectures in Memory of N.A. Kholodkovskii. Iss.57. No.1. P.1-54 [in Russian].

Pinto I.D. 1992. Carboniferous insects from Argentina 5. Narkeminidae Pinto et Ornellas, 1991 — ordo Paraplecoptera // Anais da Academia Brasileira de Ciencias. Vol.64. P.289-292.

Pinto I.D. \& Adami-Rodrigues K. 1995. A new Upper Carboniferous insect from Itarare subgroup, Parana Basin, Brazil // Pesquisas Vol.22. P.53-57.

Pinto I.D. \& Pinto de Ornellas L.P. 1980. Permian insects from the Paraná Basin, South Brazil. II - Neuroptera // Pesquisas, Porto Alegre. Vol.13. P.153-159.

Rasnitsyn A.P. \& Quicke D.L.J. (Eds). 2002. History of Insects. Dordrecht: Kluwer Academic Publishers. 517 p.

Sharov A.G. 1968. [Phylogeny of the orthopteroid insects]. Trudy Paleontol. Inst. Akad. Nauk SSSR. Vol.118. Moscow: Nauka. 218 p. [in Russian; English translation: Sharov AG. 1971. Phylogeny of the Orthopteroidea. Jerusalem: Keter Press. 251 p.]. 